\title{
Aromaterapi Lavender Essensial Oil Berpengaruh Dominan terhadap Skala Nyeri 24 Jam Post Seksio Sesaria
}

\author{
Herlyssa $^{1}$, Jehanara ${ }^{2}$, Elly Dwi Wahyuni ${ }^{3}$ \\ 1,2,3 Jurusan Kebidanan, Politeknik Kesehatan Kemenkes Jakarta III, Indonesia \\ Email: lyssafira2@gmail.com
}

\begin{abstract}
The Effect of Lavender Essential Oil Aromatherapy to The 24-hour Pain Scale of Post Sectio Caesarea (SC). This study aims to prove the effect of Lavender Essential Oil Aromatherapy to the 24-hour pain scale of post sectio caesarea (SC) in Depok District Hospital. This research is a quasi-experimental design with pre and post-test with the control group. Samples of this study are mothers who have the pain of post-SC in hospitals Depok many as 68 people were divided into a treatment group (34 people) and control group (34 people). The technique of sampling is consecutive sampling. Before the intervention, the treatment group and the control group measured the pain scale using the Numerical Rating Scale. Treatment group was given 10\% lavender essential oil aromatherapy 3 drops by using tissue media, then inhaled fragrance for 5 minutes at $10 \mathrm{~cm}$ distance. After 30 minutes of aromatherapy, patients assessed the scale of the pain. Aromatherapy is given only once at 24 hours post-SC. The results showed that the scale of pain post SC before giving aromatherapy in the control group was 3.82 while in the treatment group, it was 3.62. After giving aromatherapy it was found that the pain scale in the treatment group was 2.53, whereas in the control group 4.65. There was a significant difference of pain scale of 24 hours post SC between control group and treatment group. Lavender essential oil aromatherapy dominant influence on the reduction of pain scale of 24 hours post SC (pvalue $<0.05)$ as much as five times greater than those mothers who did not use aromatherapy. Lavender Essential Oil Aromatherapy can be used as one of the solutions in treating pain after sectio caesarea surgery.
\end{abstract}

Keywords: Aromatherapy lavender Essential Oil, Pain scale, 24 hours of Post SC

\begin{abstract}
Abstrak: Aromaterapi Lavender Essensial Oil berpengaruh Dominan terhadap Skala Nyeri 24 Jam Post Seksio Sesaria. Penelitian ini bertujuan untuk membuktikan pengaruh Aromaterapy Lavender Essensial Oil terhadap dengan skala nyeri 24 jam post sectio caesarea (SC) di RSUD Depok. Penelitian ini adalah desain quasi eksperimen dengan pre and post test with control group. Sampel penelitian ini ibu yang mengalami nyeri post SC di RSUD Depok sebanyak 68 orang yang terbagi menjadi kelompok perlakuan (34 orang) dan kelompok kontrol (34 orang). Teknik pengambilan secara consecutive sampling. Sebelum dilakukan intervensi, kelompok perlakuan dan kelompok kontrol diukur skala nyeri dengan menggunakan alat ukur Numerical Rating Scale. Kelompok perlakuan diberikan aromaterapi lavender essential oil 10\% sebanyak 3 tetes dengan mengunakan media tissue, kemudian dihirup wanginya selama 5 menit pada jarak $10 \mathrm{~cm}$. Setelah 30 menit pemberian aromaterapi, pasien dinilai skala nyerinya. Aromaterapi hanya diberikan satu kali pada 24 jam post SC. Hasil penelitian menunjukkan bahwa skala nyeri operasi yang dialami ibu post SCsebelum pemberian aromaterapi pada kelompok kontrol adalah sebesar 3.82 sedangkan pada kelompok perlakuan, adalah sebesar 3.62. Setelah pemberian aromaterapi diketahui bahwa skala nyeri pada kelompok perlakuan adalah sebesar 2,53, sedangkan pada kelompok kontrol sebesar 4,65. Ada perbedaan yang signifikan nyeri yang dialami ibu 24 jam post SC antara kelompok kontrol dengan kelompok perlakuan. Aromaterapi Lavender essensial oil berpengaruh dominan terhadap penurunan skala nyeri 24 jam post SC ( $p$-value $<0,05)$ sebanyak lima kali lebih besar dibandingkan yang ibu yang tidak menggunakan aromaterapi. Aromaterapi Lavender Essensial Oil dapat digunakan sebagai salah satu solusi dalam mengatasi nyeri setelah operasi SC.
\end{abstract}

Kata kunci: Aromaterapi lavender essensial oil, Skala nyeri, Post SC 24 jam

Sectio caesaria yang selanjutnya disingkat SC merupakan prosedur efektif untuk mengatasi ketidaknormal dalam proses persalinan (Oxon, 2010). Secara global angka kejadian $S C$ menunjukkan kenaikan empat kali lipat dalam waktu kurang dari dua dekade (Dube, 2014). Proses kelahiran bayi melalui sectio caesarea termasuk tinggi di Amerika Serikat. Tercatat 
pada tahun 2004 sebanyak $29.1 \%$ proses kelahiran bayi melalui operasi caesar. Sejak awal 1990-an The American College of Obstetricians and Gynecologist (ACOG) memutuskan berusaha meminimalkan operasi caesar secara berulang pada ibu hamil, tetapi pada kenyataannya sebanyak 33\% ibu hamil mengulangi operasi caesar pada kehamilan berikutnya (Kisner, 2007 dalam Wahyuni dan Rahman). Hasil data Riskesdas Tahun 2013, menunjukkan kelahiran dengan bedah SC di Indonesia sebesar 9,8\% dengan proporsi tertinggi di DKI Jakarta $(19,9 \%)$ dan terendah di Sulawesi Tenggara (3,3\%).

Pemberian anestesi pada pasien yang dilakukan operasi SC bertujuan agar pasien tidak merasakan nyeri saat dibedah. Namun permasalah akan timbul setelah operasi selesai ,pasien mulai sadar akan merasakan nyeri didaerah sayatan karena efek anestesi telah habis bereaksi (Dwijayanti, dkk, 2014). Nyeri dalam jangka waktu tertentu dapat menimbulkan beberapa akibat bagi pasien post SC seperti rasa tidak nyaman, cemas, tegang dan akhirnya mengganggu aktifitas fungsional sehari-hari dan produktivitas pasien sehingga akan menimbulkan berbagai masalah terhadap ibu maupun pada bayi. (Kealy, 2010). Dampak nyeri yang dirasakan oleh pasien post SC adalah mobilisasi menjadi terbatas sehingga menyebabkan pasien menunda pemberian ASI sejak awal pada bayinya, karena rasa tidak nyaman dan peningkatan tingkat nyeri setelah operasi (Dwijayanti, dkk, 2014). Pada bayi yang dilahirkan melalui sectio caesarea menjadi kurang aktif akibat efek anestesi, selain itu bayi sering mengalami gangguan pernafasan karena kelahiran yang terlalu cepat tanpa mengalami adaptasi antara dalam rahim dan luar rahim (Bobak, et al, 2005).

Nyeri setelah operasi sectio caesarea akan menimbulkan kondisi yang tidak menyenangkan. Pasien akan merasa terbatas gerakannya dan akan kesulitan dalam menyusui. Potter \& Perry (2006), menjelaskan beberapa faktor yang mempengaruhi skala nyeri diantaranya adalah pengalaman nyeri sebelumnya dan makna nyeri. Aromaterapi merupakan salah satu terapi non farmakologi yang dapat menurunkan skala nyeri setelah operasi seksio sesaria. Studi penelitian Hadi dan Hamid (2011), melaporkan bahwa Skala nyeri lebih rendah pada kelompok yang menggunakan lavender essensial oil dengan masker oksigen selama 3 menit yang diberikan setelah 3 jam pemberian analgesik dibandingkan pada kelompok kontrol. Penelitian lain oleh Dwijayanti, dkk, tahun 2014, melaporkan bahwa Skala nyeri pada 32 pasien post sectio caesarea yang diberikan inhalasi aromaterapi lavender mengalami penurunan signifikan dibandingkan sebelum diberikan perlakuan. Studi lain oleh Olapour, et al, tahun 2013 menghasilkan, penambahan anti nyeri berupa supositoria diklofenak pada kelompok plasebo secara signifikan lebih tinggi daripada kelompok yang diberikan aromaterapi lavender $(p=0,008)$. Berbeda dengan Tarsika (2008) menjelaskan bahwa aromaterapi tidak memilki pengaruh terhadap tingkat nyeri pada ibu melahirkan.

Rumah sakit umum Depok merupakan rumah sakit rujukan dari pelayanan tingkat dasar. Angka persalinan dengan sectio caesarea di RSUD Depok dari tahun ke tahun mengalami peningkatan. Mean angka sectio caesarea di RSUD Depok per bulannya adalah 40 kasus yang sebagian besar merupakan kasus rujukan dari puskesmas dan bidan praktik mandiri (BPM) di wilayah Depok dan sekitarnya. Sebagian besar pasien Post SC mengalami Skala nyeri ringan sampai berat. Berdasarkan hasil studi pendahuluan di ruang melati RSUD Depok dari 9 pasien Post SC didapatkan 33,3\% mengalami nyeri berat, $55,5 \%$ mengalami nyeri sedang, dan $11,2 \%$ mengalami nyeri ringan. Berdasarkan hasil wawancara terhadap dokter spesialis anastesi di RSUD Depok, penanganan nyeri pada pasien post SC menggunakan farmakologi diberikan analgetik dan biasanya diberikan penambahan dosis jika nyeri belum berkurang. Penelitian ini bertujuan untuk membuktikan pengaruh aromaterapi lavender essensial oil terhadap dengan skala nyeri 24 jam post sectio caesarea di RSUD Depok tahun 2015.

\section{METODE}

Penelitian ini adalah quasi eksperimen dengan pre and post test with control group. Sampel penelitian adalah sebagian ibu post $S C$ 24 jam post SC di RSUD Depok sebanyak 68 orang yang terbagi menjadi kelompok perlakuan (34 orang) dan kelompok kontrol (34 orang). Teknik pengambilan sampel dalam penelitian ini adalah dengan menggunakan teknik non probability sampling yaitu Consecutive sampling. Variabel bebas pada penelitian ini adalah skala nyeri post SC, sedangkan variabel terikat adalah intervensi aromaterapi lavender Essensial Oil serta variabel konfonding adalah umur, pengalaman nyeri, makna nyeri dan dukungan suami. Penelitian ini dimulai dengan melakukan mengukur skaka nyeri pada kelompok perlakuan dan kelompok kontrol. Setelah itu kelompok perlakuan diberikan intervensi berupa pemberian 
aromaterapi lavender essential oil 10\% sebanyak 3 tetes dengan menggunakan media tissue kemudian dihirup wanginya selama 5 menit pada jarak $10 \mathrm{~cm}$. Setelah 30 menit pemberian aromaterapi, pasien dinilai skala nyerinya. Aromaterapi hanya diberikan satu kali pada 24 jam post SC. Sedangkan pada kelompok kontrol tidak diberikan minyak Lavender essensial oil $10 \%$. Kelompok perlakuan dan kontrol terus diamati dan dinilai skala nyerinya setelah 24 jam post SC. Analisis data secara univariat, bivariat dengan T-Test independent dan Multivariat dengan Regresi Linier.

\section{HASIL}

Tabel 1. Distribusi Responden berdasarkan Karakteristiknyapada kelompok kontrol dan kelompok perlakuan

\begin{tabular}{|c|c|c|c|c|c|c|c|c|}
\hline \multirow{3}{*}{ Variabel } & \multicolumn{8}{|c|}{ Kelompok } \\
\hline & \multicolumn{4}{|c|}{ Kontrol } & \multicolumn{4}{|c|}{ Perlakuan } \\
\hline & Mean & SD & Median & $95 \% \mathrm{CI}$ & Mean & SD & Median & $95 \% \mathrm{CI}$ \\
\hline $\begin{array}{l}\text { Nyeri post SC sebelum } \\
\text { aromaterapi }\end{array}$ & 3.82 & 1.03 & 4 & $3.46-4.18$ & 3.62 & 1.56 & 3 & $3.07-4.16$ \\
\hline Umur & 28.74 & 6.60 & 29 & $26.43-31.04$ & 30.00 & 6.35 & 29 & $27.78-32.22$ \\
\hline Pengalaman Nyeri & 3.15 & 2.19 & 4 & $2.38-3.91$ & 2.97 & 2.79 & 4 & $2-3.94$ \\
\hline Makna Nyeri & 19.50 & 2.03 & 20 & $18.79-20.21$ & 19.59 & 2.51 & 20 & $18.71-20.46$ \\
\hline Dukungan Suami & 20.56 & 1.67 & 20 & $19.98-21.14$ & 20.47 & 2.79 & 21 & $19.5-21.44$ \\
\hline Nyeri Post SC & 4.65 & 1.10 & 5 & $4.26-5.03$ & 2.53 & 1.35 & 2 & $2.06-3$ \\
\hline
\end{tabular}

Mean skala Nyeri operasi post SC sebelum dilakukan intervensi hampir sama antara kelompok kontrol dan kelompok perlakuan. Sedangkan Mean skala nyeri setelah dilakukan intervensi terlihat bahwa kelompok kontrol lebih tinggi dari pada kelompok kontrol. Mean umur ibu hampir sama pada kelompok kontrol dan kelompok perlakuan. Mean Pengalaman nyeri pada kelompok kontrol lebih tinggi dibandingkan pada kelompok perlakuan. Mean makna nyeri hampir sama antara kelompok perlakuan dan kelompok kontrol. Mean dukungan suami juga hampir sama pada kelompok kontrol dan kelompok perlakuan.

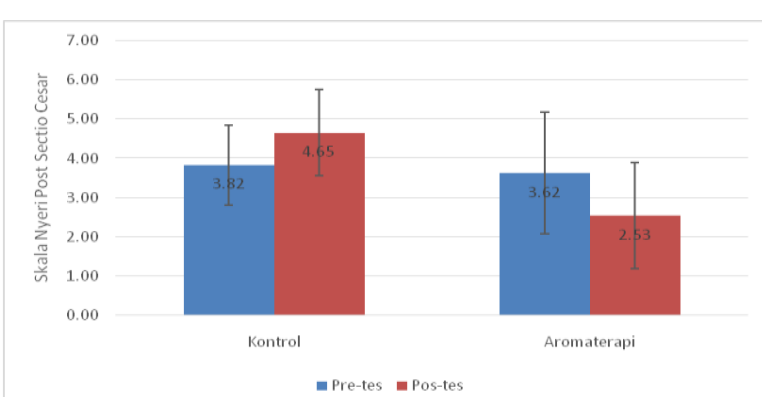

Gambar 1. Mean skala Nyeri akut Post SC Sebelum dan SesudahDiberikan Aromaterapi

Pada Gambar 1 ditunjukkan bahwa meanskala nyeri post SC sebelum dilakukan intervensi hampir sama pada kelompok kontrol dan kelompok perlakuan. Setelah dilakukan intervensi, pada kelompok kontrol terlihat ada peningkatan mean nyeri 24 jam post SC sedangkan pada kelompok perlakuan lebih rendah dari pada mean skala nyeri sebelum perlakuan. Hal ini mengindikasikan bahwa pemberian aromaterapi mampu menurunkan nyeri post $\mathrm{SC}$.

Tabel 2. Pengujian Pengaruh Aromaterapi terhadap Nyeri Post SC

\begin{tabular}{|c|c|c|c|c|}
\hline \multirow[b]{2}{*}{ Kelompok } & \multicolumn{2}{|c|}{ Mean \pm SD } & \multirow{2}{*}{$\begin{array}{c}\text { t- } \\
\text { hitung }\end{array}$} & \multirow{2}{*}{$\begin{array}{c}p- \\
\text { value }\end{array}$} \\
\hline & Pre-test & $\begin{array}{c}\text { Post- } \\
\text { test }\end{array}$ & & \\
\hline Kontrol & $\begin{array}{c}3.82 \pm \\
1.03\end{array}$ & $\begin{array}{c}4.65 \pm \\
1.1\end{array}$ & -6.338 & 0.000 \\
\hline Aromaterapi & $\begin{array}{c}3.62 \pm \\
1.56\end{array}$ & $\begin{array}{c}2.53 \pm \\
1.35\end{array}$ & 6.371 & 0.000 \\
\hline
\end{tabular}

Berdasarkan hasil pengujian dengan menggunakan uji t berpasangan, pada kelompok aromaterapi, didapatkan p-value sebesar 0.000 $(p<0.05)$. Dari hasil pengujian ini terbukti bahwa pemberian aromaterapi lavender essential oil terbukti mampu menurunkan nyeri post SC secara signifikan. Sedangkan pada kelompok kontrol, juga didapatkan p-value sebesar 0.000 $(p<0.05)$. Dari pengujian ini menunjukkan bahwa pada kelompok kontrol, terjadi peningkatan nyeri post SC secara signifikan. 


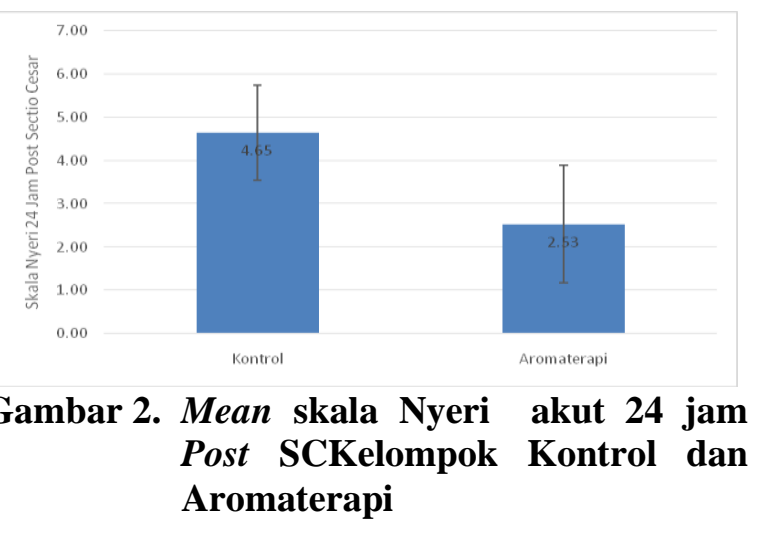

Berdasarkan pada gambar 2, dijelaskan bahwa nyeri 24 jam post SC pada kelompok kontrol lebih tinggi dari pada kelompok aromaterapi. Berikut hasil perbandingan pengaruh aromaterapi terhadap nyeri persalinan 24 jam post SC dengan menggunakan independen $t$-test:
Tabel 3. Perbandingan Nyeri akut post SC dengan Independen $t$-test

\begin{tabular}{lrrr}
\multicolumn{1}{c}{ Kelompok } & Mean \pm SD & t-hitung & p-value \\
\hline Kontrol & $4.65 \pm 1.1$ & 7.085 & 0.000 \\
Aromaterapi & $2.53 \pm 1.35$ & & \\
\hline
\end{tabular}

Berdasarkan pada hasil analisis dengan menggunakan uji $\mathrm{t}$ independen, didapatkan $p$ value sebesar 0,000 , lebih kecil daripada $\alpha=0,05$ $(p>0,05)$. Dari pengujian ini dapat disimpulkan bahwa terdapat perbedaan yang signifikan nyeri yang dialami ibu 24 jam post SC antara kelompok kontrol dengan kelompok aromaterapi. Dari hasil pengujian ini telah terbukti bahwa pemberian aromaterapi lavender essential oil efektif dalam menurunkan nyeri post SC.

Tabel 4. Analisis Korelasi dan Regresi skala nyeri post SC,pengalaman nyeri, dan makna nyeri, dengan skala nyeri 24 jam post $\mathrm{SC}$

\begin{tabular}{lcccc}
\hline \multicolumn{1}{c}{$\begin{array}{c}\text { Variabel } \\
\text { Independen }\end{array}$} & $\mathbf{r}$ & $\mathbf{R}^{\mathbf{2}}$ & Persamaan garis & p-value \\
\hline Umur ibu & 0,066 & 0,004 & $\begin{array}{c}\text { Skala nyeri } 24 \text { jam post } \mathrm{SC} \\
=2,512+0,011^{*} \text { umur ibu }\end{array}$ & 0,593 \\
\hline $\begin{array}{l}\text { nyeri operasi } \\
\text { sebelum } \\
\text { pemberian } \\
\text { aromaterapi }\end{array}$ & 0,616 & 0,379 & $\begin{array}{c}\text { skala nyeri } 24 \text { jam post } \mathrm{SC}=0,943+0,509^{*} \\
\text { skala nyeri post } \mathrm{SC}\end{array}$ & 0,000 \\
\hline $\begin{array}{l}\text { Pengalaman nyeri } \\
\text { Makna nyeri }\end{array}$ & 0,196 & 0,039 & $\begin{array}{c}\text { Skala nyeri24 jam post } \mathrm{SC}=2,576+0,086^{*} \\
\text { skala nyeri sebelumya }\end{array}$ & 0,108 \\
\hline Dukungan suami & 0,121 & 0,015 & $\begin{array}{c}\text { Skala nyeri24 jam post } \mathrm{SC}=1,706+0,058^{*} \\
\text { makna nyeri }\end{array}$ & 0,326 \\
\hline
\end{tabular}

Berdasarkan pada hasil analisis dengan menggunakan analisis korelasi regresi di atas, ditunjukkan bahwa variabel umur, makna nyeri, pengalaman nyeri, dan dukungan suami memiliki p-value lebih dari 0.05 ( $p>0.05)$. Hubungan skala nyeri operasi sebelum perlakuan dengan Skala nyeri 24 jam post SC menunjukkan hubungan yang kuat $(\mathrm{r}=0,616)$ dan berpola positif dengan $\mathrm{P}$ value sebesar $0.000(p<0.05)$. Hasil uji statistik menunjukkan ada hubungan yang signifikan antara nyeri operasi dengan Skala nyeri 24 jam post SC.
Tabel 5. Hasil pemodelan awal Analisis Multivariat

\begin{tabular}{lc}
\hline \multicolumn{1}{c}{ Variabel } & p-value \\
\hline Umur ibu & 0,198 \\
\hline $\begin{array}{l}\text { Nyeri operasi } \\
\text { perlakuan }\end{array}$ & sebelum \\
\hline Pengalaman nyeri & 0,000 \\
\hline Aromaterapi & 0,239 \\
\hline Makna Nyeri & 0,068 \\
\hline Dukungan suami & 0,092 \\
\hline
\end{tabular}

Dari tabel 5 diketahui bahwa variabel umur ibu, skala nyeri post SC sebelum perlakuan, aromaterapi, makna nyeri dan dukungan suami memiliki $p$-value $<0,25$ sehingga dapat dianjutkan ke pemodelan selanjutnya. Namun mengingat riwayat nyeri sebelumnya secara substtansi merupakan faktor yang penting terhadap Skala nyeri 24 jam post SC sehingga tetap dimasukkan ke dalam pemodelan selanjutnya. 
Setelah dilakukan uji asumsi terhadap Asumsi eksistensi (mean $=0,000$ ), indepedensi (koefisien durbin watson=1,881, Homoscedascity (tebaran memiliki pola yang sama), normalitas (data menyebar di sekitar garis disgonal dan mengikuti arah garis diagonal), diketahui bahwa seluruh uji asumsi terpenuhi. Selain itu juga dilakukan Diagnostik multicollinearity, diketahui tidak ada multicollinearity antara sesama variabel independen (nilai $\mathrm{VIF}=1,249$ ). Berdasarkan uji asumsi dan kolinearitas ternyata uji asumsi terpenuhi sehingga model dapat digunakan untuk memprediksi skala nyeri 24 jam post SC. Uji Interaksi tidak dilakukan mengingat secara substansi antar variabel dipandang tidak ada interaksi. Adapun hasil pemodelan terakhir pada analisis multivariat adalah sebagai berikut.

Tabel 6. Hasil Pemodelan terakhir Analisis Mutivariat

\begin{tabular}{|c|c|c|c|}
\hline Variabel & $\overline{\mathbf{R}^{2}}$ & Beta & p-value \\
\hline Aromaterapi & 0,499 & 0,413 & 0,000 \\
\hline Umur ibu & & $-0,029$ & \\
\hline $\begin{array}{l}\text { Skala nyeri } \\
\text { post } \mathrm{SC} \\
\text { sebelum } \\
\text { intervensi }\end{array}$ & & $-0,153$ & \\
\hline $\begin{array}{l}\text { Pengalaman } \\
\text { nyeri }\end{array}$ & & $-0,658$ & \\
\hline Makna Nyeri & & 0,081 & \\
\hline $\begin{array}{l}\text { Dukungan } \\
\text { suami }\end{array}$ & & $-0,065$ & \\
\hline
\end{tabular}

Dari tabel 6 diketahui bahwa nilai $\mathrm{R}^{2}$ sebesar 0,499 artinya model regresi yang diperoleh dapat menjelaskan $49,9 \%$ variasi skala nyeri 24 jam post SC. Dari hasil analisi statistik juga diperoleh $p$-value sebesar 0,000 berarti bahwa pada alpha 5\% menyatakan bahwa model regresi dapat memprediksi skala nyeri 24 jam post SC. Dari nilai Beta diketahui bahwa Aromaterapi merupakan faktor yang paling dominan dalam menurunkan lima kali lebih besar skala nyeri 24 jam Post SC setelah dikontrol oleh variabel skala nyeri post SC, umur ibu, pengalaman nyeri, dan makna nyeri dan dukungan suami.

\section{PEMBAHASAN}

Hasil penelitian menunjukkan bahwa mean nyeri operasi sebelum pemberian aromaterapi pada kelompok kontrol dan kelompok perlakuan hampir sama. Setelah diberikan aromaterapi, pada kelompok kontrol terlihat ada peningkatan mean nyeri 24 jam post
SC sedangkan pada kelompok perlakuan lebih rendah dari pada mean skala nyeri sebelum perlakuan. Hal ini mengindikasikan bahwa pemberian aromaterapi mampu menurunkan nyeri post SC. Pada kelompok kontrol, didapatkan skala nyeri post test terjadi peningkatan nyeri 24 jam post SC. Hal ini sesuai dengan Hadi dan Hamid (2011), melaporkan bahwa skala nyeri lebih rendah pada kelompok yang menggunakan lavender essensial oil dibandingkan pada kelompok kontrol.

Metode pemberian aromaterapi yang dilakukan terhadap sampel sedikit berbeda antara peneliti dan Hadi dan Hamid (2011). Peneliti menggunakan aromaterapi lavender essensial oil $10 \%$ diteteskan 3 tetes pada tissue kemudian diberikan pada ibu post SC 24 jam dan dihirup selama 5 menit pada jarak $10 \mathrm{~cm}$, kemudian dilakukan pengukuran skala nyeri (post test) pada kelompok perlakuan dan kelompok kontrol, setelah 5 menit aromaterapi diberikan dengan menunjukkan gambar skala nyeri dari 1-10 sesuai lembar observasi. Sedangkan Hadi dan Hamid (2011), menggunakan aromaterapi yang diteteskan ke masker oksigen selama 3 menit, setelah 3 jam pemberian analgesik. Baik metode inhalasi dengan masker oksigen maupun dengan dihirup secara langsung membuktikan bahwa aromaterapi lavender essensial oil dapat menurunkan skala nyeri post SC.

Penelitian ini juga sesuai dengan Dwijayanti, dkk, (2014), yang melaporkan bahwa skala nyeri pada 32 pasien post SC yang diberikan inhalasi aromaterapi lavender mengalami penurunan signifikan dibandingkan sebelum diberikan perlakuan. Begitu juga dengan Studi lain oleh Olapour, et al, (2013), yang menghasilkan penambahan anti nyeri berupa supositoriadiklofenak pada kelompok plasebo secara signifikan lebih tinggi daripada kelompok yang diberikan aromaterapi lavender $(p=0,008)$. Pada penelitian ini juga tidak diberikan tambahan obat anti nyeri karena terbukti pemberian aromaterapi lavender essential oil efektif dalam menurunkan nyeri post SC. Berdasarkan hasil analisis dengan uji $\mathrm{t}$ independen, didapatkan $p$ value sebesar 0,000 , lebih kecil daripada $\alpha=0,05$ $(p>0,05)$. Dari pengujian ini dapat disimpulkan bahwa terdapat perbedaan yang signifikan nyeri yang dialami ibu 24 jam post SC antara kelompok kontrol dengan kelompok aromaterapi. Hal ini juga sesuai dengan Rahmawati (2015) yang menyebutkan bahwa aromaterapi lavender dan aromaterapi lemon efektif dalam menurunkan skala nyeri post sectio caesarea dengan $p$-value $0,009(p<0,05)$. 
Aromatherapi merupakan salah satu terapi non farmakologis untuk mengurangi nyeri persalinan, yaitu terapi komplementer yang melibatkan penggunaan wewangian berasal dari minyak esensial. Minyak esensial dapat dikombinasikan dengan base oil yang dapat dihirup atau di massage ke kulit yang utuh (Brooker, 2009 dalam Hongratanaworakit, 2009). Aromaterapi dipercaya dapat meningkatkan oksigenisasi dan nutrisi bagi sel dan jaringan, menurunkan endorphine yang nantinya akan meningkatkan relaksasi mental dan fisik (Clarke, 2008 dalam Yang, Wang, and Wang, 2016).

Cara kerja minyak esensial sebagai aromaterapi adalah molekul-molekul minyak esensial diterima oleh sel-sel reseptor dalam lapisan hidung ketika dihirup akan mengirimkan sinyal-sinyal ke otak. Peran elektrokimia yang diterima oleh pusat penciuman dalam otak kemudian merangsang pelepasan kimia-kimia saraf yang sangat kuat ke dalam darah yang kemudian diangkut ke seluruh tubuh. Molekulmolekul yang dihirup ke dalam paru bisa memasuki aliran darah dan diedarkan ke seluruh tubuh dengan cara yang sama (Gidds \& Grosset, 2000). Minyak esensial akan menembus pori-pori kulit dan folikel-folikel rambut ketika digosokkan atau dipijat pada kulit. Minyak esensial akan masuk ke dalam pembuluh darah kapiler kemudian tersebar ke seluruh tubuh. (Gidds \& Grosset, 2000). Kondisi inilah yang mengakibatkan berkurangnya skala nyeri pada ibu post SC.

Namun hasil penelitian ini berbeda dengan Tarsika (2008), yang menyebutkan bahwa aromaterapi tidak memilki pengaruh terhadap tingkat nyeri pada ibu melahirkan. Dari hasil pengujian ini terbukti bahwa pemberian aromaterapi lavender essential oil terbukti mampu menurunkan nyeri post SC secara signifikan. Sedangkan pada kelompok kontrol, juga didapatkan $p$-value sebesar $0.000(\mathrm{p}<0.05)$. Dari pengujian ini menunjukkan bahwa pada kelompok kontrol, terjadi peningkatan nyeri post SC secara signifikan.

Ketidaksesuaian ini kemungkinan disebabkan dari perbedaan karakteristik nyeri yang terjadi pada sampel yaitu antara ibu melahirkan dan ibu post SC. Prawirohardjo (2008), menjelaskan bahwa nyeri persalinan atau His merupakan nyeri fisiologis. Nyeri ini akan timbul sejak permulaan kala I, dan amplitudonya terus meningkat hingga $60 \mathrm{mmHg}$ pada akhir kala I. Frekuensi His pada akhir kala I dapat mencapai 4 kali dalam 10 menit dengan lama 6090 etik. Nyeri persalinan atau His sangat diperlukan agar persalinan dapat berlangsung secara normal. Selama His abdomen akan terasa mengeras dan menimbulkan rasa tidak nyaman (rasa nyeri). Rasa nyeri yang dirasakan sebagai rasa sakit punggung. Dalam perkembangannya His akan menjadi lebih lama dan kuat yang mengakibatkan skala nyeri yang dirasakan semakin bertambah. Sedangkan Nyeri post SC merupakan nyeri yang timbul akibat luka sayatan pisau saat operasi berlangsung.

Aromaterapi Essensial Lavender oil adalah salah satu aromaterapi yang berbentuk cairan atau minyak. Aroma terapi ini mengandung lavender yang membantu memudahkan tidur, meredakan kegelisahan, mengatasi masalah depresi, mengurangi perasaan ketegangan (OGCCU, 2013).

Berdasarkan analisis korelasi regresi, penelitian ini telah menunjukkan bahwa variabel umur, kelahiran, makna nyeri, pengalaman nyeri, dan dukungan suami memiliki $p$-value lebih dari 0.05 ( $p>0.05)$. Hubungan nyeri operasi dengan Skala nyeri 24 jam post SC menunjukkan hubungan yang kuat $(\mathrm{r}=0,616)$ dan berpola positif dengan $p$-value sebesar $0.000(p<0.05)$. Hasil uji statistik menunjukkan ada hubungan yang signifikan antara nyeri operasi dengan Skala nyeri 24 jam post $\mathrm{SC}$.

Dari hasil analisis multivariat diketahui bahwa nilai $\mathrm{R}^{2}$ sebesar 0,499 artinya model regresi yang diperoleh dapat menjelaskan $49,9 \%$ variasi Skala nyeri 24 jam post SC. Dari hasil analisi statistik juga diperoleh $p$-value sebesar 0,000 berarti bahwa pada alpha $5 \%$ menyatakan bahwa model regresi dapat memprediksi Skala nyeri 24 jam post SC. Dari nilai Beta diketahui bahwa Aromaterapi merupakan faktor yang paling dominan dalam menurunkan lima kali lebih besar terhadap Skala nyeri 24 jam Post SC setelah dikontrol oleh variabel umur ibu, Skala nyeri post SC sebelum intervensi, pengalaman nyeri, makna nyeri dan dukungan suami.

\section{SIMPULAN}

Aromaterapi merupakan faktor yang paling dominan dalam menurunkan lima kali lebih besar terhadap skala nyeri 24 jam Post SC. Perlu dilakukan penelitian yang lebih besar lagi, dengan bentuk aromaterapi yang lain dan aroma yang berbeda, sampel dan variabel yang lebih banyak dan dilakukan di beberapa tempat, sehingga diharapkan hasilnya lebih baik lagi. 


\section{SARAN}

Aromaterapi dapat digunakan sebagai salah satu solusi untuk mengurangi nyeri post SC. Peneliti selanjutnya dapat menggunakan sampel yang lebih banyak dan dilakukan di beberapa tempat. Bidan perlu meningkatkan pengetahuannyatentang penggunaan Aromaterapi dalam pelayanan kebidanan khususnya pada ibu post SC.

\section{DAFTAR PUSTAKA}

Bobak, M. Irene, et. al. 2005. Buku Ajar Keperawatan Maternitas. Edisi 4. Alih. Bahasa: Maria A. Wijayarini. Jakarta: EGC.

Dube, J. V., Kshirsagar N. S. 2014. Effect of Planned Early Recommended Ambulation Technique on Selected Post caesarean Biophysiological Health Parameters. JKIMSU. Vol. 3, No. 1.

Dwijayanti, Wening, Sumatrini Sri, Arianti Ida. 2014. Efek Aroma Terapi Lvender Inhalasi Terhadap Skala Nyeri Paska Sectio Caesarea. Med Host. Vol.2 (2): $120-12$.

Gidds \& Grosset, 2000. Alternative Therapies. Yogyakarta: Lotus

Hadi, N., Hamid, A.A. 2011. Lavender Essence for Post-cesarean Pain. Pak J Biol Sci. 14(11):664-7.

Hongratanaworakit, Tapanee. 2009. Simultaneous Aromatherapy Massage with Rosemary Oil on Humans. Journal of Scientia Pharmaceutica 77(2):375-387.

Kealy, et al. 2010. Recovery after caesarean birth: a qualitative study of women's accounts in Victoria. Australia: BMC Pregnancy and Childbirth. 10:47

OGCCU. 2013. Aromatherapy. Obstetric and Midwifery Guidelines.

Olapour A, Behaeen K, Akhondzadeh R, Soltani F, al Sadat Raavi. 2013. The Effect of Inhalation of Aromatheraphy Blend Containing Lavender Essential Oil on Cesarean Postoperative Pain. Anesth pain. $3(1): 203-7$

Oxon, H. et al. 2010. Ilmu Kebidanan: Patologi \& Fisiologi Persalinan. Yogyakarta: Yayasan Essentia Medica.
Potter \& Perry 2006. Buku Ajar Fundamental Keperawatan: Konsep, Proses, dan Praktik. Edisi 4. Volume 2. http. www. repository.usu.ac.id/bitstream/.../45807/.../. Jakarta: EGC.

Prawirohardjo, S. 2008. Ilmu Kebidanan. Jakarta: YBPSP.

Riskesdas. 2013. Riset Kesehatan Dasar. Jakarta: Kemenkes RI.

Rahmawati, I., \& Rohmayanti, R. 2015. Efektivitas Aromaterapi Lavender Dan Aromaterapi Lemon Terhadap Intensitas Nyeri Post Sectio Caesarea (Sc) Di Rumah Sakit Budi Rahayu Kota Magelang. Journal of Holistic Nursing Science, 2(2), 10-16.

Tarsika. 2008. Efektifitas Relaksasi Aromaterapi Terhadap Tingkat Nyeri Kala I Fase Aktif Pada Ibu Melahirkan Di RSIA Sakina Idaman Sleman Yogyakarta. [Karya Tulis Ilmiah]. Yogyakarta: Fakultas kedokteran Universitas Muhammadiyah Jogyakarta.

Wahyuni, Farid Rahman. 2013. Pengaruh Penambahan Teknik Relaksasi Progresif Pada Terapi Latihan terhadap Penurunan Nyeri Post Sectio Caesarea di Rumah Sakit Umum Daerah Dr. Moewardi. Seminar Nasional Kesehatan, Universitas Muhammadiyah Surakarta. https://publikasiilmiah.ums.ac.id.

Yang, Ya Ping, Wang Chi Jane and Jing Jy Wang. 2016. Effect of Aromatherapy Massage on Agitation and Depressive Mood in Individuals With Dementia. Journal of Gerontological Nursing September 2016 Volume 42. Issue 9: 3846. 